\title{
Herbicide Programs for Control of Glyphosate-Resistant Volunteer Corn in Glufosinate-Resistant Soybean
}

\author{
Parminder S. Chahal and Amit J. Jhala*
}

Glyphosate-resistant (GR) volunteer corn is a significant problem weed in soybean grown in rotation with corn in the midwestern United States and eastern Canada. The objective of this study was to evaluate the efficacy of glufosinate applied in single or sequential applications compared with acetylcoenzyme A carboxylase (ACCase) inhibitors applied alone or tank mixed with glufosinate for controlling GR volunteer corn in glufosinate-resistant soybean. At $15 \mathrm{~d}$ after early-POST (DAEP), ACCase inhibitors applied alone controlled volunteer corn 76 to $93 \%$ compared to 71 to $82 \%$ control when tank mixed with glufosinate. The expected volunteer corn control achieved by tank mixing ACCase inhibitors and glufosinate was greater than the glufosinate alone, indicating that glufosinate antagonized ACCase inhibitors at 15 DAEP, but not at later rating dates. ACCase inhibitors applied alone or tank mixed with glufosinate followed by late-POST glufosinate application controlled volunteer corn and green foxtail $\geq 97 \%$ at 30 DAEP. Single early-POST application of glufosinate controlled common waterhemp and volunteer corn 53 to $78 \%$, and green foxtail 72 to $93 \%$ at 15 DAEP. Single as well as sequential glufosinate applications controlled green foxtail and volunteer corn greater than or equal to $90 \%$, and common waterhemp greater than $85 \%$ at $75 \mathrm{~d}$ after late-POST (DALP). Contrast analysis suggested that glufosinate applied sequentially provided greater control of volunteer corn at 15 and 75 DALP compared to a single application. Similar results were reflected in volunteer corn density and biomass at 75 DALP. Volunteer corn interference did not affect soybean yield, partly because of extreme weather conditions (hail and high winds) in both years of this study.

Nomenclature: Clethodim; fenoxaprop-P; fluazifop-P; glufosinate; quizalofop-P; sethoxydim; common waterhemp, Amaranthus rudis Sauer; green foxtail, Setaria viridis (L.) Beauv.; soybean, Glycine max (L.) Merr.; volunteer corn, Zea mays L.

Key words: Antagonism, herbicide interaction, resistance management, weed control.

\begin{abstract}
El maíz voluntario resistente a glyphosate (GR) es un problema significativo de malezas en soja producida en rotación con maíz en el centro oeste de los Estados Unidos y en el este de Canadá. El objetivo de este estudio fue evaluar la eficacia de glufosinate aplicado solo o en aplicaciones secuenciales comparado con inhibidores de acetyl-coenzyme A carboxylase (ACCase) aplicados solos o en mezclas en tanque con glufosinate para el control de maíz GR voluntario en soja resistente a glufosinate. A 15 d después de la aplicación POST temprana (DAEP), los inhibidores de ACCase aplicados solos controlaron el maíz voluntario 76 a $93 \%$ comparado con 71 a $82 \%$ de control con la mezcla en tanque con glufosinate. El control esperado de maíz voluntario con las mezclas en tanque con ACCase y glufosinate fue mayor que el de glufosinate solo, lo que indicó que glufosinate antagonizó a los inhibidores de ACCase a 15 DAEP, pero no en fechas de evaluación posteriores. Los inhibidores de ACCase aplicados solos o en mezclas en tanque con glufosinate seguidos de aplicaciones tardías POST de glufosinate controlaron el maíz voluntario y Setaria viridis $\geq 97 \%$ a 30 DAEP. Aplicaciones POST tempranas de glufosinate solo controlaron Amaranthus rudis y maíz voluntario 53 a $78 \%$, y $S$. viridis 72 a $93 \%$ a 15 DAEP. Aplicaciones solas y secuenciales de glufosinate controlaron $S$. viridis y maíz voluntario en $90 \%$ o más, y $A$. rudis más de $85 \%$ a 75 d después de la aplicación POST tardía (DALP). Análisis de contrastes sugirieron que glufosinate aplicado secuencialmente brindó mayor control del maíz voluntario a 15 y 75 DALP al compararse con una única aplicación. Resultados similares fueron observados en la densidad y biomasa del maíz voluntario a 75 DALP. La interferencia del maíz voluntario no afectó el rendimiento de la soja, parcialmente porque se presentaron condiciones extremas del estado del tiempo (granizo y vientos fuertes) en los dos años de este estudio.
\end{abstract}

\footnotetext{
DOI: $10.1614 /$ WT-D-15-00001.1

* Graduate Research Assistant and Assistant Professor, Department of Agronomy and Horticulture, University of Nebraska-Lincoln, Lincoln, NE 68583-0915. Corresponding author's E-mail: Amit.Jhala@unl.edu
}

GR corn and soybean have been widely adopted crops in the United States since commercialization in 1998 and 1996, respectively (Castle et al. 2006). In the United States, 94\% of soybean and $89 \%$ of corn planted in 2014 were herbicide resistant, 
primarily GR (USDA 2014). Increased adoption of GR corn has resulted in volunteer corn becoming a problem weed in GR soybean grown in rotation (Davis et al. 2008). Volunteer corn is overwintering $\mathrm{F}_{2}$ generation of corn hybrids grown in the previous year or a corn hybrid emerging from a failed corn stand in a corn-replant situation (Shauck and Smeda 2012; Steckel et al. 2009). Volunteer corn is a competitive weed that results in significant yield reduction of crops grown in rotation (Beckett and Stoller 1988; Chahal et al. 2015; Clewis et al. 2008; Wilson et al. 2010). Volunteer corn encourages the dispersal and survival of western corn rootworm (Diabrotica virgifera virgifera LeConte) and gray leaf spot disease (Cercospora zeae-maydis Tehon \& E. Y. Daniels), thus limiting the benefits of a cornsoybean rotation (Krupke et al. 2009; Marquardt et al. 2012; Shaw et al. 1978). If not controlled, volunteer corn may interfere with soybean harvest and reduce seed quality (Deen et al. 2006).

Before the commercialization of GR corn and soybean, volunteer corn was controlled with glyphosate with the use of rope wick applicators in conventional soybean (Andersen et al. 1982; Andersen and Geadelmann 1982). Volunteer corn plants; however, were required to grow taller than soybean canopy before glyphosate treatment, allowing early-season competition that usually results in reduced soybean yield (Andersen et al. 1982). A recent study reported that $\mathrm{PRE}$ herbicides registered for weed control in soybean provided unacceptable control of GR volunteer corn (Chahal et al. 2014). Several studies reported that the acetyl-coenzyme A carboxylase (ACCase)-inhibiting herbicides provided effective POST control of volunteer corn in soybean (Beckett and Stoller 1988; Beckett et al. 1992; Chahal et al. 2014; Deen et al. 2006; Young and Hart 1997). However, efficacy of these herbicides can vary depending on growth stage, type of ACCase inhibitors applied, environmental conditions at the time of application, and distribution of volunteer corn (Deen et al. 2006; Wilson et al. 2010). The overreliance on glyphosate for weed control in corn and soybean in the last $17 \mathrm{yr}$ has resulted in the evolution of GR weeds (Beckie and Hall 2014; Owen 2008), and as of 2014, 29 weed species worldwide have evolved resistance to glyphosate, including 14 species in the United States (Heap 2014a). Therefore, alternate herbicide programs are required for controlling GR weeds and limiting continued evolution of resistance (Aulakh and Jhala 2015; Ganie et al. 2015; Jhala et al. 2014; Sarangi et al. 2015).

Glufosinate is a nonselective, contact, POST herbicide that inhibits the synthesis of glutamine synthetase in sensitive plants (Wendler et al. 1990; Wild and Wendler 1991) and results in the accumulation of a toxic level of ammonia within the cell, causing photosynthesis cessation, disruption of chloroplast structure, and vesiculation of stroma (Devine et al. 1993; Hinchee et al. 1993). Before the commercialization of glufosinate-resistant corn and soybean, application of glufosinate was limited to noncrop areas, preplant applications in reduced tillage system, and weed control in orchards and vineyards (Coetzer et al. 2002; Jhala et al. 2013; Singh and Tucker 1987). However, glufosinate-resistant crops have provided growers an opportunity to apply glufosinate POST to control many troublesome weeds, including glyphosate-resistant giant ragweed (Ambrosia trifida L.) (Jhala et al. 2014; Kaur et al. 2014).

Glufosinate is a broad-spectrum herbicide that controls many weeds (Anonymous 2014). Steckel et al. (1997) reported at least $80 \%$ control of $10-\mathrm{cm}$ tall common cocklebur (Xanthium strumarium L.), giant foxtail (Setaria faberi Herrm.), and Pennsylvania smartweed (Polgonum pensylvanicum L.) with glufosinate application. Glufosinate is effective for controlling certain weed species that are difficult to control with glyphosate, such as Ipomoea spp., hemp sesbania [Sesbania exaltata (Raf.) Rydb. ex A.W. Hill] (Askew at al. 1997; Corbett et al. 2004), and Amaranthus species resistant to glyphosate (Coetzer et al. 2002; Culpepper et al. 2009; Whitaker et al. 2011a).

Glufosinate is usually more effective on annual broadleaf weeds than on grasses (Corbett et al. 2004; Culpepper et al. 2000; Steckel et al. 1997). For example, Culpepper et al. (2000) reported more than $80 \%$ control of common lambsquarters (Chenopodium album L.), and prickly sida (Sida spinosa L.) with a single application of glufosinate compared to less than $75 \%$ control of broadleaf signalgrass [Urochloa platyphylla (Nash) R.D. Webster], goosegrass [Eleusine indica (L.) Gaertn.], and johnsongrass [Sorghum halepense (L.) Pers.]. However, variable control of volunteer corn has been reported. Shauck and Smeda (2012) reported $<80 \%$ control of GR corn hybrids when glufosi- 
nate was applied to 10 - and 40-cm-tall plants compared to $20 \mathrm{~cm}(>80 \%$ control) in a cornreplant situation. Steckel et al. (2009) also reported variability in glufosinate efficacy depending on the height of volunteer corn plants. In contrast, Terry et al. (2012) reported no difference in control of GR corn hybrids and their progenies with glufosinate.

Glufosinate can be applied sequentially in glufosinate-resistant corn and soybean. According to the label, a single glufosinate application up to $740 \mathrm{~g}$ ai ha ${ }^{-1}$ can be made in soybean, with a cumulative 1,340 per growing season (Anonymous 2014). Earnest et al. (1998) reported $\geq 90 \%$ control of barnyardgrass [Echinochloa crus-galli (L.) Beauv.], when glufosinate was applied sequentially in glufosinate-resistant corn. Similarly, Aulakh et al. (2011) reported $\geq 97 \%$ control of large crabgrass [Digitaria sanguinalis (L.) Scop.], Palmer amaranth [Amaranthus palmeri S. Wats.], sicklepod [Senna obtusifolia (L.) H.S. Irwin \& Barneby], and smallflower morningglory [Jacquemontia tamnifolia (L.) Griseb.] with glufosinate applied sequentially. Therefore, sequential applications of glufosinate or tank mixing glufosinate with ACCase inhibitors may provide better control of GR volunteer corn in glufosinate-resistant soybean. However, several studies also reported that when tank mixed with ACCase inhibitors, glufosinate antagonized control of some annual and perennial grasses (Burke et al. 2005; Gardner at al. 2006). However, information is not available on efficacy of ACCase inhibitors applied in tank mix with glufosinate for control of volunteer corn.

A recent survey reported that cultivation of glufosinate-resistant soybean is increasing in the midsouthern United States, specifically for control of GR Palmer amaranth (Aulakh et al. 2013; Barnett et al. 2013). It is further likely that the cultivation of glufosinate-resistant soybean in the midwestern United States may increase in the near future to control GR weeds more effectively (Kaur et al. 2014), including volunteer corn (Chahal et al. 2014). There is no information in the scientific literature on the efficacy of glufosinate applied alone at different rates or when tank mixed with ACCase inhibitors for control of GR volunteer corn in glufosinate-resistant soybean. The objectives of this study were (1) to compare the efficacy of glufosinate applied at different rates in single or sequential applications for control of GR volunteer corn, (2) to compare the efficacy of ACCase inhibitors applied alone or tank mixed with glufosinate in an earlyPOST followed by a late-POST application of glufosinate for control of GR volunteer corn and other weeds, and (3) to evaluate crop injury and yield of glufosinate-resistant soybean in presence of GR volunteer corn.

\section{Materials and Methods}

Field experiments were conducted at the South Central Agricultural Laboratory (SCAL), University of Nebraska-Lincoln, near Clay Center, NE in 2013 and 2014. Soil was a Crete silt loam (fine, montmorillonitic, mesic, Pachic Argiustolls) with a $\mathrm{pH}$ of $6.5,17 \%$ sand, $58 \%$ silt, $25 \%$ clay, and $2.5 \%$ organic matter. GR hybrid corn (Mycogen 2G 681) was seeded at 35,000 seeds $\mathrm{ha}^{-1}$ in rows spaced 76 $\mathrm{cm}$ apart on May 23, 2013 and May 6, 2014. This project was initiated in 2012 by hand-planting volunteer corn seeds collected in the fall of 2011; however, emergence was poor $\left(<4\right.$ plants plot $\left.^{-1}\right)$ which was not sufficient to test several herbicide programs included in this study. Therefore, in 2013 and 2014 glyphosate-resistant hybrid corn was planted at a density of 35,000 seeds ha ${ }^{-1}$ to mimic volunteer corn, which resulted in excellent corn emergence both years. Glufosinate-resistant soybean ('Stine 30 LC 28') was seeded perpendicular to the corn rows at a density of 380,000 seeds ha ${ }^{-1}$ in rows spaced $76 \mathrm{~cm}$ apart on May 28, 2013 and May 8, 2014. The experiment was arranged in a randomized complete block design with four replications. Plots were $3 \mathrm{~m}$ wide and $9 \mathrm{~m}$ long, consisting of four soybean rows.

A tank mixture of glyphosate (Roundup PowerMAX, Monsanto Company, 800 North Lindberg Ave., St. Louis, MO) at $1.06 \mathrm{~kg}$ ae ha ${ }^{-1}$ plus $S$ metolachlor (Dual II Magnum, Syngenta Crop Protection, Inc., Greensboro, NC 27419) at 1.63 $\mathrm{kg}$ ai ha ${ }^{-1}$ was applied to the entire experimental area for the control of emerged weeds and residual control of annual grasses $2 \mathrm{~d}$ before seeding corn. Herbicide treatments included glufosinate applied at different rates in single or sequential applications, and ACCase inhibitors (clethodim, fenoxaprop plus fluazifop, fluazifop, quizalofop, or sethoxydim) applied alone or tank mixed with glufosinate applied early-POST and followed by a late-POST application of glufosinate (Table 1). A nontreated 


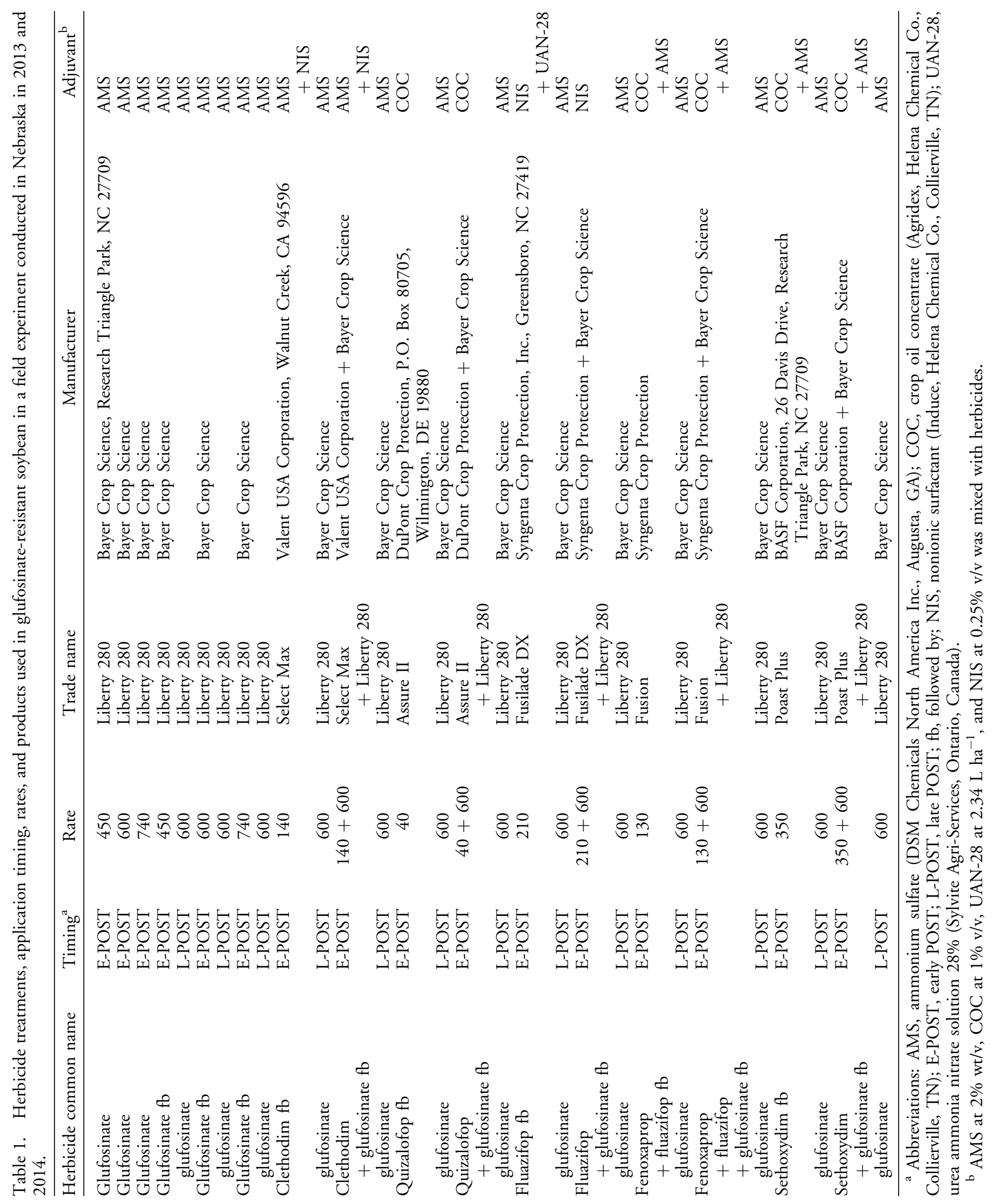

434 - Weed Technology 29, July-September 2015 
control was included for comparison. The application rates of herbicides were selected based on the manufacturer's recommended rates in glufosinateresistant soybean.

Herbicide treatments were applied with a $\mathrm{CO}_{2-}$ pressurized backpack sprayer consisting of a fournozzle boom fitted with AIXR 110015 flat-fan nozzles (TeeJet Spraying Systems Co., P.O. Box 7900, Wheaton, IL 60189) calibrated to deliver $140 \mathrm{~L} \mathrm{ha}^{-1}$ at $276 \mathrm{kPa}$. GR volunteer corn was 25 to $30 \mathrm{~cm}$ tall and soybean was at the V2 to V3 stage at the time of early-POST application of herbicides (June 26, 2013 and June 10, 2014). Glufosinate at $600 \mathrm{~g} \mathrm{ha}^{-1}$ was applied late-POST in selected treatments (Table 1) on July 12, 2013 and June 26, 2014 when volunteer corn was 32 to $38 \mathrm{~cm}$ tall and soybean was at the V5 to V6 stage.

Visual control estimates were recorded for volunteer corn and other existing weeds at $15 \mathrm{~d}$ after early POST (DAEP) and 15, 30, 45, and $75 \mathrm{~d}$ after late-POST (DALP) herbicide treatments based on 0 to $100 \%$ scale, where $0 \%$ equals no control and $100 \%$ equals plant death. A similar scale was used to assess glufosinate-resistant soybean injury at 7 and $21 \mathrm{~d}$ after early- and late-POST herbicide applications, where $0 \%$ equals no foliar injury and $100 \%$ equals plant death. The density and biomass were assessed from two randomly selected $0.25-\mathrm{m}^{2}$ quadrats per plot at 45 DALP herbicide treatment. The aboveground biomass of volunteer corn and other weeds was hand harvested separately and oven dried at $65 \mathrm{C}$ for $3 \mathrm{~d}$, and dry weight was recorded. Soybean was harvested at maturity with a small-plot combine, weight and moisture content were recorded, and yields were adjusted to $13 \%$ moisture content.

Statistical Analysis. Data for visual weed control estimates, density, and biomass, and soybean injury and yield were subjected to ANOVA without the PROC GLIMMIX procedure in SAS version 9.3 (SAS Institute Inc., Cary, NC 27513). Year and treatments were considered fixed effects, whereas replication was considered a random effect in the model. Biomass data of common waterhemp were arc-sine square-root transformed before analysis; however, data presented are the means of actual values for comparison based on interpretation from the transformed data. Where the ANOVA indicated treatment effects were significant, means were separated at $\mathrm{P} \leq 0.05$ with the use of the Tukey-
Kramer pairwise comparison test. Additionally, the PROC GLIMMIX procedure was used to test single-degree-of-freedom contrasts to compare the effect of different herbicide programs. Preplanned contrasts were performed to compare herbicide programs containing single vs. sequential glufosinate applications, and programs containing ACCase inhibitors applied alone vs. ACCase inhibitors tank mixed with glufosinate. Expected values for herbicide interactions were calculated with the use of Colby equation (Colby 1967):

$$
E=(X+Y)-(X Y / 100),
$$

where $E$ is the expected control of GR volunteer corn or green foxtail with application of herbicides $\mathrm{A}+\mathrm{B}$ in tank mixture, $X$ and $Y$ are observed control of GR volunteer corn or green foxtail with the application of herbicides $A$ and $B$, respectively, at specific rates. The expected and observed control values for herbicide combination $\mathrm{A}+\mathrm{B}$ were subjected to $t$ tests to determine whether means were different. The herbicide combination was considered antagonistic if the expected mean was significantly greater than the observed mean. If the expected mean was significantly lower than the observed mean, the herbicide combination was considered synergistic.

\section{Results and Discussion}

The interaction of year by treatment was not significant for visual weed control estimates, density, biomass, soybean injury and yield; therefore, data were pooled over years. Glufosinate applied at 450 , 600 , and $740 \mathrm{~g} \mathrm{ha}^{-1}$ provided 66,73 , and $75 \%$ control of GR volunteer corn, respectively. The ACCase-inhibiting herbicides, applied alone, provided $\geq 93 \%$ control, except for sethoxydim, which provided $76 \%$ control of GR volunteer corn (Table 2). Similarly, Soltani et al. (2006) reported $<80 \%$ control of GR volunteer corn with sethoxydim compared to $>85 \%$ control with other ACCase inhibitors (clethodim, fenoxaprop-P, fluazifop-P, quizalofop-P) at 28 DAT. Volunteer corn was controlled 71 to $82 \%$ when ACCase inhibitors were tank mixed with glufosinate compared to 76 to $96 \%$ control when applied alone at 15 DAEP, indicating possible antagonism when tank mixed with glufosinate. The Colby analysis also showed that the expected volunteer corn control achieved by 
Table 2. Effect of herbicide treatments on glyphosate-resistant volunteer corn control, density, and biomass in glufosinate-resistant soybean in a field experiment conducted in Nebraska in 2013 and 2014. ${ }^{\mathrm{a}}$

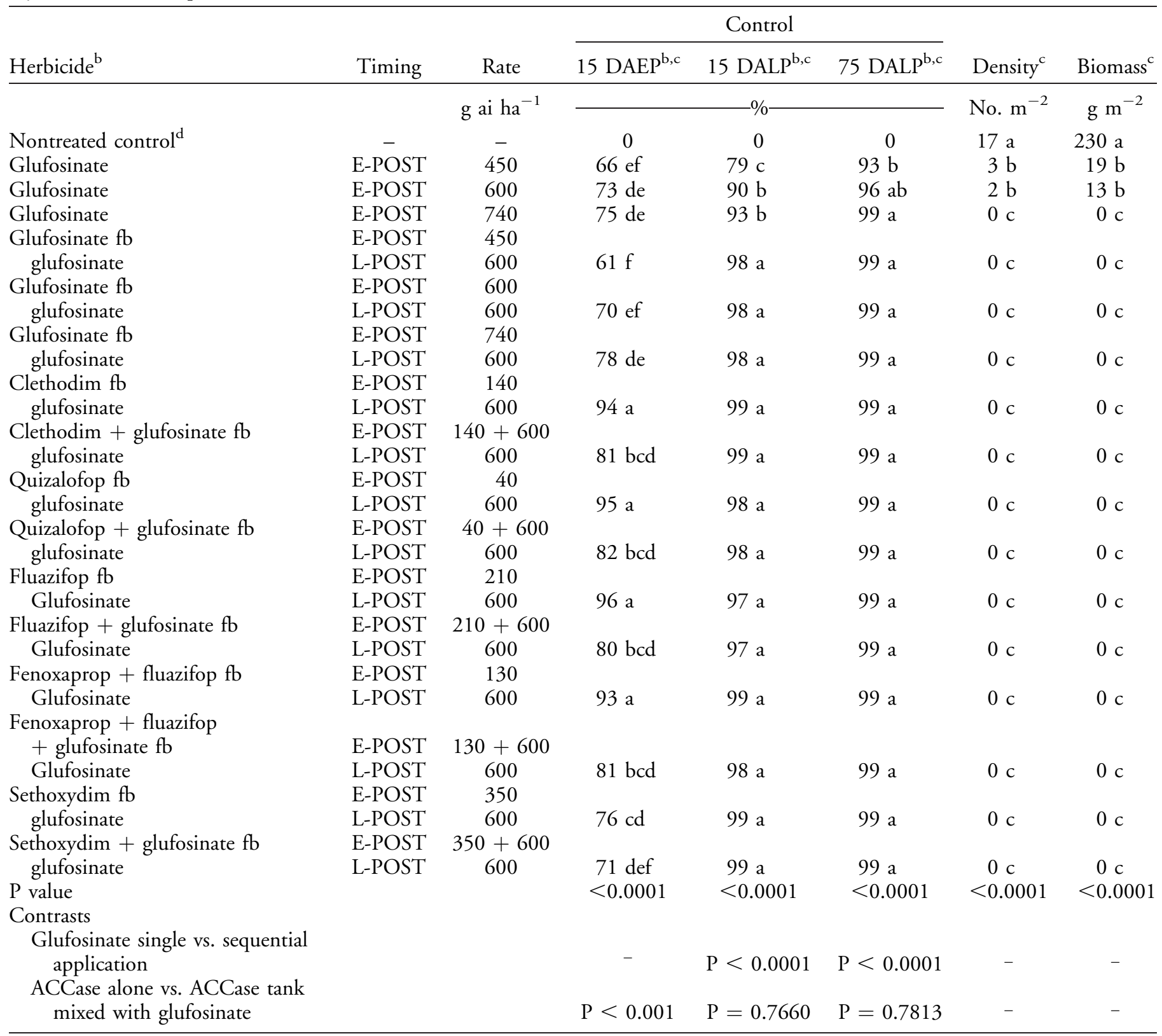

a Year-by-treatment interaction was not significant; therefore, data from both years were combined.

b Abbreviations: E-POST, early POST; L-POST, late POST; DAEP, days after early POST; DALP, days after late POST; fb, followed by.

${ }^{\mathrm{c}}$ Means within columns with no common letter(s) are significantly different according to Tukey-Kramer's pairwise comparison test at $\mathrm{P} \leq 0.05$.

$\mathrm{d}$ The percent control $(0 \%)$ data of nontreated control were not included in analysis.

tank mixing ACCase inhibitors and glufosinate was greater than their respective observed control at 15 DAEP (Table 3), indicating that glufosinate antagonized ACCase inhibitors. This is consistent with previous studies that have reported antagonism of the ACCase-inhibiting herbicides when tank mixed with some broadleaf herbicides (Culpepper et al. 1998, 1999; Holshouser and Coble 1990; Vidrine et al. 1995). For instance, Burke et al. (2005) reported a 50\% reduction in goosegrass 
Table 3. Observed and expected control of glyphosate-resistant volunteer corn by acetyl-coenzyme A carboxylase (ACCase) inhibitors applied alone or tank mixed with glufosinate in glufosinate-resistant soybean at $15 \mathrm{~d}$ after early-POST (DAEP) in a field experiment conducted in 2013 and 2014 in Nebraska.

\begin{tabular}{|c|c|c|c|}
\hline Herbicide & Rate & Observed & Expected $^{\mathrm{a}}$ \\
\hline & $\mathrm{g}$ ai ha ${ }^{-1}$ & 0 & \\
\hline Glufosinate & 600 & 73 & \\
\hline Clethodim & 140 & 94 & \\
\hline Clethodim + glufosinate & $140+600$ & 81 & $98^{\mathrm{b}}$ \\
\hline Quizalofop & 40 & 95 & \\
\hline Quizalofop + glufosinate & $40+600$ & 82 & $99^{\mathrm{b}}$ \\
\hline Fluazifop & 210 & 96 & \\
\hline Fluazifop + glufosinate & $210+600$ & 80 & $99^{\mathrm{b}}$ \\
\hline Fenoxaprop + fluazifop & 130 & 93 & \\
\hline \multicolumn{4}{|l|}{ Fenoxaprop + fluazifop } \\
\hline+ glufosinate & $130+600$ & 81 & $98^{\mathrm{b}}$ \\
\hline Sethoxydim & 350 & 76 & \\
\hline Sethoxydim + glufosinate & $350+600$ & 71 & $97^{b}$ \\
\hline LSD $(0.05)$ & & 10 & \\
\hline
\end{tabular}

${ }^{\text {a }}$ Expected value determined by the Colby equation: $E=(X+$ $Y)-(X Y / 100)$, where $E$ is expected percent control with herbicide $\mathrm{A}+\mathrm{B}, X$ and $Y$ is observed percent control with herbicide $\mathrm{A}$ and $\mathrm{B}$, respectively.

b Significantly different from the observed value $(\mathrm{P} \leq 0.05)$ as determined by $t$ test, indicating antagonism of tank mixing herbicides $\mathrm{A}$ and $\mathrm{B}$.

control when clethodim was tank mixed with glufosinate compared to clethodim applied alone. No difference in GR volunteer corn control was observed with sethoxydim applied alone $(76 \%)$ or tank mixed with glufosinate (71\%).

At 30 DAEP, glufosinate applied at 450, 600, and $740 \mathrm{~g} \mathrm{ha}^{-1}$ provided 79, 90, and 93\% control of GR volunteer corn, respectively. Shauck and Smeda (2012) reported 80 to $85 \%$ control of $20-\mathrm{cm}-$ tall GR corn with glufosinate applied at $450 \mathrm{~g} \mathrm{ha}^{-1}$. An early-POST followed by a late-POST application of glufosinate improved volunteer corn control $\geq 98 \%$ at 15 DALP. A similar level of volunteer corn control $(\geq 97 \%)$ was observed with ACCase inhibitors applied alone or tank mixed with glufosinate when followed by a late-POST application of glufosinate. Similarly, Beyers et al. (2002) reported improved control of common waterhemp, giant foxtail, pitted morningglory (Ipomoea lacunosa L.), ivyleaf morningglory [Ipomoea hederacea (L.) Jacq.], and prickly sida, with sequential applications of glufosinate. By 75 DALP, volunteer corn control was $>90 \%$ with all herbicide treatments. However, on the basis of contrasts, sequential applications of glufosinate provided greater control of volunteer corn at 15 and 75 DALP compared to a single glufosinate application, and no difference was observed in contrast analysis between ACCase inhibitors applied alone vs. tank mixed with glufosinate at 15 and 75 DALP glufosinate treatment (Table 2).

Similar results were observed in volunteer corn density and biomass. For example, the nontreated control had the highest volunteer corn density (17 plants $\mathrm{m}^{-2}$ ) and biomass $\left(230 \mathrm{~g} \mathrm{~m}^{-2}\right)$ followed by a single application of glufosinate at $450 \mathrm{~g} \mathrm{ha}^{-1}(19 \mathrm{~g}$ $\left.\mathrm{m}^{-2}\right)$ and $600 \mathrm{~g} \mathrm{ha}^{-1}\left(13 \mathrm{~g} \mathrm{~m}^{-2}\right)$, and the remaining treatments resulted in no volunteer corn biomass. No crop injury was observed in any of herbicide treatments at 7 and $21 \mathrm{~d}$ after early- and late-POST treatments during either year of the study (data not shown). This was expected because glufosinateresistant soybean usually has high level of tolerance to glufosinate applications; however, some level of injury has been reported in literature. For example, Beyers et al. (2002) reported 7 to $21 \%$ glufosinateresistant soybean injury at $14 \mathrm{~d}$ after glufosinate applied in combination with quizalofop, lactofen, or imazethapyr compared to $<12 \%$ injury with glufosinate applied alone. In another study, Culpepper et al. (2000) reported 30 to $34 \%$ injury on glufosinate-resistant soybean, in one out of three site years, at $5 \mathrm{~d}$ after glufosinate applied alone or in combination with fomesafen.

In addition to volunteer corn, the primary weeds in the experimental area were green foxtail and common waterhemp. Green foxtail emergence was partially due to lack of activation of $S$-metolachlor because of limited available moisture early in the season during both years. At 15 DAEP, green foxtail control was influenced by glufosinate rates. Glufosinate applied at 450,600, and $740 \mathrm{~g} \mathrm{ha}^{-1}$ provided 72 to 75,81 to 84 , and 92 to $93 \%$ control, respectively (Table 4). Similarly, Bethke et al. (2013) reported greater control (86\%) of giant foxtail with glufosinate applied at higher rates compared to the lower rates (73 to $76 \%$ ). The ACCase inhibitors applied alone or tank mixed with glufosinate controlled green foxtail $>87 \%$ at 15 DAEP, indicating no antagonism when tank mixed with glufosinate. The Colby analysis also showed that the expected control of green foxtail by tank mixing ACCase inhibitors and glufosinate was comparable with their respective observed control at 15 DAEP (Table 5). Similarly, Johnson et al. 
Table 4. Effect of herbicide treatments on green foxtail control in glufosinate-resistant soybean in a field experiment conducted in Nebraska in 2013 and 2014. ${ }^{\mathrm{a}}$

\begin{tabular}{|c|c|c|c|c|c|}
\hline \multirow[b]{2}{*}{ Herbicide $^{\mathrm{b}}$} & \multirow[b]{2}{*}{ Timing } & \multirow[b]{2}{*}{ Rate } & \multicolumn{3}{|c|}{ Control } \\
\hline & & & $15 \mathrm{DAEP}^{\mathrm{b}, \mathrm{c}}$ & 15 DALP $^{\mathrm{b}, \mathrm{c}}$ & 75 DALP $^{\mathrm{b}, \mathrm{c}}$ \\
\hline & & $\mathrm{g}$ ai ha ${ }^{-1}$ & & $-\%-$ & 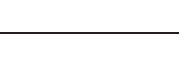 \\
\hline Nontreated control $^{\mathrm{d}}$ & - & - & 0 & 0 & 0 \\
\hline Glufosinate & E-POST & 450 & $75 \mathrm{~d}$ & $91 \mathrm{~b}$ & $99 \mathrm{a}$ \\
\hline Glufosinate & E-POST & 600 & $84 \mathrm{c}$ & $90 \mathrm{~b}$ & $99 \mathrm{a}$ \\
\hline Glufosinate & E-POST & 740 & $92 \mathrm{a}$ & $94 \mathrm{ab}$ & 99 a \\
\hline $\begin{array}{l}\text { Glufosinate } \mathrm{fb} \\
\text { glufosinate }\end{array}$ & $\begin{array}{l}\text { E-POST } \\
\text { L-POST }\end{array}$ & $\begin{array}{l}450 \\
600\end{array}$ & $72 \mathrm{~d}$ & $93 \mathrm{ab}$ & $99 \mathrm{a}$ \\
\hline $\begin{array}{l}\text { Glufosinate } \mathrm{fb} \\
\text { glufosinate }\end{array}$ & $\begin{array}{l}\text { E-POST } \\
\text { L-POST }\end{array}$ & $\begin{array}{l}600 \\
600\end{array}$ & $81 \mathrm{c}$ & $94 \mathrm{ab}$ & $99 \mathrm{a}$ \\
\hline $\begin{array}{l}\text { Glufosinate } \mathrm{fb} \\
\text { glufosinate }\end{array}$ & $\begin{array}{l}\text { E-POST } \\
\text { L-POST }\end{array}$ & $\begin{array}{l}740 \\
600\end{array}$ & $93 \mathrm{a}$ & $98 \mathrm{ab}$ & $99 \mathrm{a}$ \\
\hline $\begin{array}{l}\text { Clethodim fb } \\
\text { glufosinate }\end{array}$ & $\begin{array}{l}\text { E-POST } \\
\text { L-POST }\end{array}$ & $\begin{array}{l}140 \\
600\end{array}$ & $91 \mathrm{a}$ & $99 \mathrm{a}$ & 99 a \\
\hline $\begin{array}{l}\text { Clethodim }+ \text { glufosinate } \mathrm{fb} \\
\text { glufosinate }\end{array}$ & $\begin{array}{l}\text { E-POST } \\
\text { L-POST }\end{array}$ & $\begin{array}{l}140+600 \\
600\end{array}$ & $92 \mathrm{a}$ & $99 \mathrm{a}$ & $99 \mathrm{a}$ \\
\hline $\begin{array}{l}\text { Quizalofop fb } \\
\text { glufosinate }\end{array}$ & $\begin{array}{l}\text { E-POST } \\
\text { L-POST }\end{array}$ & $\begin{array}{r}40 \\
600\end{array}$ & $93 \mathrm{a}$ & $99 \mathrm{a}$ & 99 a \\
\hline $\begin{array}{l}\text { Quizalofop }+ \text { glufosinate } \mathrm{fb} \\
\text { glufosinate }\end{array}$ & $\begin{array}{l}\text { E-POST } \\
\text { L-POST }\end{array}$ & $\begin{array}{l}40+600 \\
600\end{array}$ & $91 \mathrm{a}$ & $99 \mathrm{a}$ & 99 a \\
\hline $\begin{array}{l}\text { Fluazifop fb } \\
\text { glufosinate }\end{array}$ & $\begin{array}{l}\text { E-POST } \\
\text { L-POST }\end{array}$ & $\begin{array}{l}210 \\
600\end{array}$ & $91 \mathrm{a}$ & 99 a & 99 a \\
\hline $\begin{array}{l}\text { Fluazifop }+ \text { glufosinate } \mathrm{fb} \\
\text { glufosinate }\end{array}$ & $\begin{array}{l}\text { E-POST } \\
\text { L-POST }\end{array}$ & $\begin{array}{l}210+600 \\
600\end{array}$ & $90 \mathrm{ab}$ & 99 a & 99 a \\
\hline $\begin{array}{l}\text { Fenoxaprop }+ \text { fluazifop } \mathrm{fb} \\
\text { glufosinate }\end{array}$ & $\begin{array}{l}\text { E-POST } \\
\text { L-POST }\end{array}$ & $\begin{array}{l}130 \\
600\end{array}$ & $91 \mathrm{ab}$ & 99 a & 99 a \\
\hline $\begin{array}{l}\text { Fenoxaprop }+ \text { fluazifop }+ \text { glufosinate } \mathrm{fb} \\
\text { glufosinate }\end{array}$ & $\begin{array}{l}\text { E-POST } \\
\text { L-POST }\end{array}$ & $\begin{array}{c}130+600 \\
600\end{array}$ & $92 \mathrm{a}$ & 99 a & 99 a \\
\hline $\begin{array}{l}\text { Sethoxydim } \mathrm{fb} \\
\text { glufosinate }\end{array}$ & $\begin{array}{l}\text { E-POST } \\
\text { L-POST }\end{array}$ & $\begin{array}{l}350 \\
600\end{array}$ & $87 \mathrm{bc}$ & 99 a & 99 a \\
\hline $\begin{array}{l}\text { Sethoxydim }+ \text { glufosinate } \mathrm{fb} \\
\text { glufosinate }\end{array}$ & $\begin{array}{l}\text { E-POST } \\
\text { L-POST }\end{array}$ & $\begin{array}{l}350+600 \\
600\end{array}$ & $91 \mathrm{ab}$ & 99 a & 99 a \\
\hline $\begin{array}{l}\text { P value } \\
\text { Contrasts }\end{array}$ & & & $<0.0001$ & 0.0023 & 0.4604 \\
\hline Glufosinate single vs. sequential application & & & - & $\mathrm{P}=0.8208$ & $\mathrm{P}=0.8968$ \\
\hline ACCase alone vs. ACCase tank mixed with glufosinate & & & $\mathrm{P}=0.5312$ & $\mathrm{P}=1.0000$ & $\mathrm{P}=0.7721$ \\
\hline
\end{tabular}

${ }^{a}$ Year-by-treatment interaction was not significant; therefore, data from both years were combined.

b Abbreviations: DAEP, days after early POST; DALP, days after late POST; E-POST, early POST; fb, followed by; L-POST, late POST.

${ }^{\mathrm{c}}$ Means within columns with no common letter(s) are significantly different according to the Tukey-Kramer pairwise comparison test at $\mathrm{P} \leq 0.05$.

${ }^{d}$ The percent control (0\%) data of nontreated control were not included in analysis.

(2014) reported $>90 \%$ control of johnsongrass with tank-mixed application of clethodim and glufosinate as early-POST followed by a late-POST glufosinate. Abit et al. (2011) reported >90\% control of green foxtail with quizalofop applied alone. Control of green foxtail was $\geq 90 \%$ in all herbicide treatments at 15 DALP. On the basis of contrasts, late-POST glufosinate application did not improve green foxtail control compared to a single application of glufosinate at 15 or 75 DALP. At 75 DALP, all herbicide treatments provided 99\% control of green foxtail. Similarly, Corbett et al. (2004) reported $>95 \%$ control of green and yellow foxtail [Setaria pumila (Poir.) Roemer \& J.A. Schultes] with single or sequential applications of glufosinate at 291 and $409 \mathrm{~g} \mathrm{ha}^{-1}$. The nontreated 
Table 5. Observed and expected control of green foxtail by acetyl-coenzyme A carboxylase (ACCase) inhibitors applied alone or tank mixed with glufosinate in glufosinate-resistant soybean at $15 \mathrm{~d}$ after early POST (DAEP) in a field experiment conducted in Nebraska in 2013 and 2014.

\begin{tabular}{|c|c|c|c|}
\hline Herbicide & Rate & Observed & Expected $^{\mathrm{a}}$ \\
\hline & $\mathrm{g}$ ai ha ${ }^{-1}$ & $-c$ & \\
\hline Glufosinate & 600 & 84 & \\
\hline Clethodim & 140 & 91 & \\
\hline Clethodim + glufosinate & $140+600$ & 92 & $99^{\mathrm{b}}$ \\
\hline Quizalofop & 40 & 93 & \\
\hline Quizalofop + glufosinate & $40+600$ & 91 & $99^{b}$ \\
\hline Fluazifop & 210 & 91 & \\
\hline Fluazifop + glufosinate & $210+600$ & 90 & $99^{\mathrm{b}}$ \\
\hline Fenoxaprop + fluazifop & 130 & 91 & \\
\hline \\
\hline+ glufosinate & $130+600$ & 92 & $99^{b}$ \\
\hline Sethoxydim & 350 & 87 & \\
\hline Sethoxydim + glufosinate & $350+600$ & 91 & $98^{\mathrm{b}}$ \\
\hline LSD $(0.05)$ & & 9 & \\
\hline
\end{tabular}

${ }^{a}$ Expected value determined by the Colby's equation: $E=(X+$ $Y)-(X Y / 100)$, where $E$ is expected percent control with herbicide $\mathrm{A}+\mathrm{B}, X$ and $Y$ is observed percent control with herbicide $\mathrm{A}$ and $\mathrm{B}$, respectively.

${ }^{\mathrm{b}}$ Not significantly different from the observed value $(\mathrm{P} \leq$ $0.05)$, as determined by $t$ test.

control had the highest green foxtail biomass (29 g $\mathrm{m}^{-2}$ ), and no biomass was present in any of the herbicide-treated plots (data not shown).

A single application of glufosinate provided variable control of common waterhemp at 15 DAEP; the highest rate $\left(740 \mathrm{~g} \mathrm{ha}^{-1}\right)$ provided $76 \%$ control compared to less than $65 \%$ at the lower rates (Table 6). The ACCase inhibitors applied alone provided no control of common waterhemp, and their tank-mixed application with glufosinate provided 60 to $65 \%$ control. At 15 and 75 DALP, 85 to $95 \%$ control of common waterhemp was observed with a single application of glufosinate, and the sequential applications (irrespective of glufosinate rate) provided $\geq 93 \%$ control. Similarly, Beyers et al. (2002) reported $93 \%$ control of common waterhemp with sequential applications of glufosinate compared to a single application (85\%). At 75 DALP, all herbicide treatments provided $\geq 86 \%$ control of common waterhemp. However, based on the contrasts, sequential applications of glufosinate provided greater control of common waterhemp at 75 DALP compared to a single application. Sarangi et al. (2015) reported $>85 \%$ control of GR common waterhemp with a single glufosinate application at $594 \mathrm{~g} \mathrm{ha}^{-1}$. The highest biomass $\left(327 \mathrm{~g} \mathrm{~m}^{-2}\right.$ ) of common waterhemp was recorded in the nontreated control plots compared to $<70 \mathrm{~g} \mathrm{~m}^{-2}$ in herbicidetreated plots with no difference among them (data not shown).

No difference in soybean yield was observed between herbicide treatments, partly because of the effects of hail- and windstorms on plants later in the season during both years. Results of this study conclude that glufosinate applied in single or sequential applications can effectively control GR volunteer corn in glufosinate-resistant soybean. However, ACCase inhibitors controlled green foxtail and GR volunteer corn more effectively than a single application of glufosinate early in the season (15 DAEP). The control was comparable with both groups of herbicides later in the season. Results suggested that ACCase inhibitors can be applied tank mixed with glufosinate without any injury on glufosinate-resistant soybeans. However, glufosinate reduced GR volunteer corn control when tank mixed with ACCase inhibitors at 15 DAEP and therefore, a late-POST application of glufosinate is needed to maximize volunteer corn control. Glufosinate applied in single or sequential applications provided greater than $85 \%$ control of GR volunteer corn along with other weeds; however, herbicide programs based on a single herbicide or herbicides with the same mode of action favor selection pressure and, if used repeatedly, result in the evolution of herbicide-resistant weeds (Beckie and Tardif 2012). In fact, two weed species have evolved resistance to glufosinate worldwide (Heap 2014b), including Italian ryegrass (Lolium perenne L. ssp. multiflorum), currently the only known glufosinateresistant species in the United States (Avila-Garcia et al. 2012). Therefore, glufosinate should be carefully incorporated into herbicide programs along with herbicides with other modes of action in glufosinate-resistant soybean (Aulakh and Jhala 2015; Johnson et al. 2014; Kaur et al. 2014).

The objective of this study was to control GR volunteer corn in glufosinate-resistant soybean, and because PRE herbicides registered in soybean are not effective for controlling volunteer corn (Chahal et al. 2014), herbicide programs in this study were based on glufosinate and/or ACCase inhibitors, which are not the best programs for managing other weeds (such as common waterhemp). Several 
Table 6. Effect of herbicide treatments on common waterhemp control, density, biomass, and soybean yield in glufosinate-resistant soybean in a field experiment conducted in Nebraska in 2013 and 2014. ${ }^{a}$

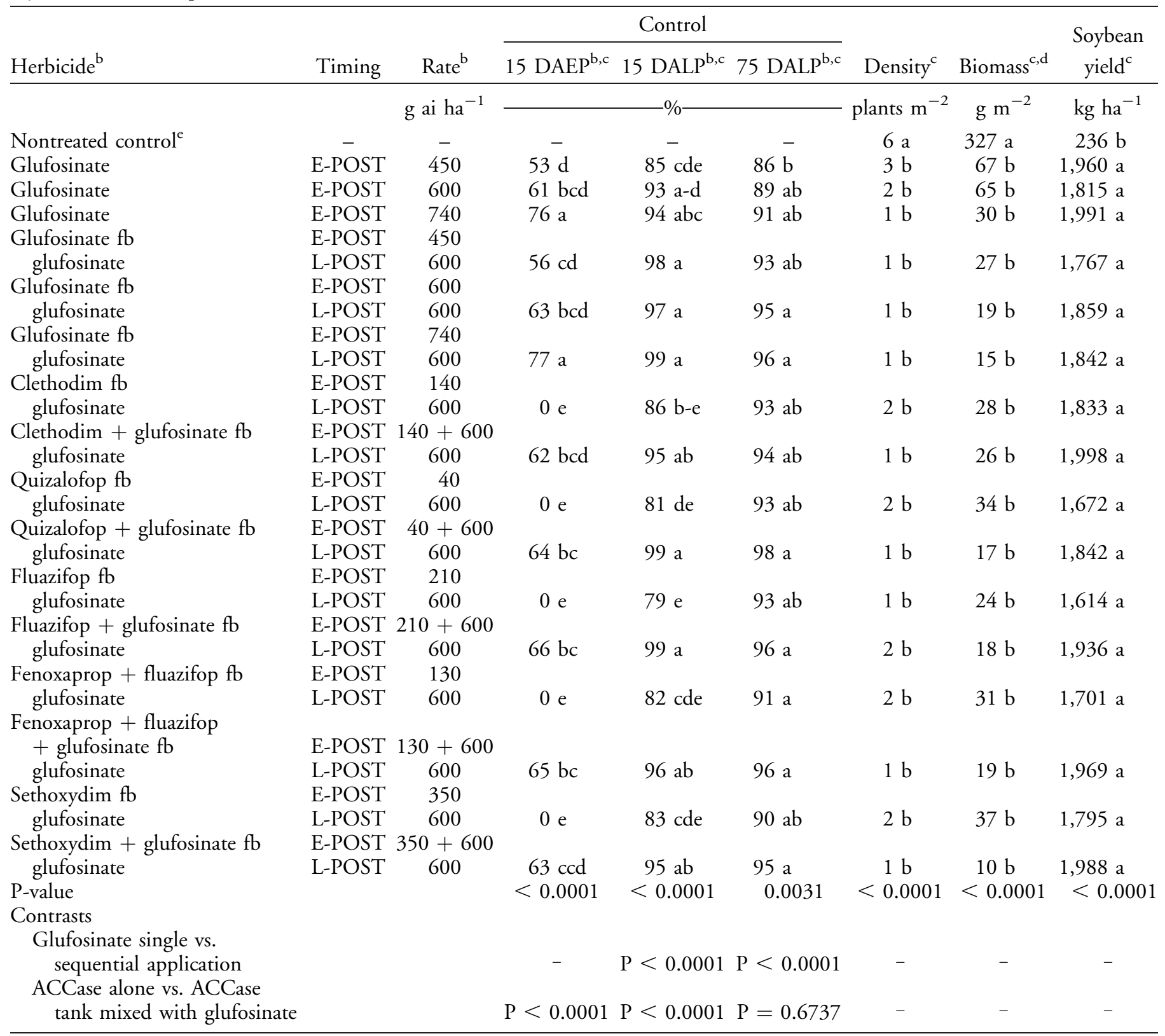

${ }^{a}$ Year-by-treatment interaction was not significant; therefore, data from both years were combined.

b Abbreviations: DAEP, days after early POST; DALP, days after late POST; E-POST, early POST; fb, followed by; L-POST, late POST.

${ }^{\mathrm{c}}$ Means within columns with no common letter(s) are significantly different according to the Tukey-Kramer pairwise comparison test at $\mathrm{P} \leq 0.05$.

$\mathrm{d}$ Biomass data were arc-sine square-root transformed before analysis; however, data presented are the means of actual values for comparison based on interpretation from the transformed data.

e The percent control $(0 \%)$ data of nontreated control were not included in analysis.

studies reported that the use of residual herbicides and herbicides with different modes of action is an important component of weed management programs (Aulakh et al. 2012; Whitaker et al. 2011b).
Therefore, an integrated weed management approach is necessary for controlling existing herbicide-resistant weeds and to limit the evolution of new herbicide-resistant weeds (Norsworthy et al. 
2012). The results of this study indicate that a high level of GR volunteer corn control can be achieved through glufosinate in single or sequential applications; however, continuous use of glufosinate alone may result in the evolution of glufosinate-resistant weeds (Avila-Garcia et al. 2012; Jalaludin et al. 2010). Additionally, we believe that use of glyphosate-resistant hybrid corn vs. true volunteer corn would have slightly impacted the results because several factors, including the active growth of the plant, determine the plant's response to an herbicide application. Therefore, the use of hybrid corn seeds over volunteer corn (F2 corn seed) in this study might have resulted in slight overestimation of volunteer corn control because using F2 corn may have reduced vigor (Jugenheimer 1976) and ultimately may have slightly reduced response to herbicides compared to hybrid corn.

The results of this study are limited for controlling GR volunteer corn in glufosinateresistant soybean because glufosinate will not be an effective option for control of GR volunteer corn in all situations. For example, glyphosate plus glufosinate-resistant corn hybrid is available in the marketplace; thus glufosinate will not be an effective option for controlling volunteer corn if hybrid corn planted the previous year is stacked resistant. Additionally, multiple herbicide-resistant crops, including corn resistant to 2,4-D, glyphosate, aryloxyphenoxy propionate, and glufosinate may be commercialized in the near future (Craigmyle et al. 2013), leaving cyclohexanedione herbicides as the only option for volunteer corn control (Sikkema and Soltani 2014).

\section{Acknowledgments}

This project was partially funded by the United States Department of Agriculture (USDA) $-\mathrm{Na}$ tional Institute of Food and Agriculture (NIFA) Grant 10748998. Authors acknowledge Irvin Schleufer for his help in this project and Dr. Greg Kruger and Dr. Humberto Blanco for useful discussions.

\section{Literature Cited}

Abit MJM, Al-Khatib K, Olson BL, Stahlman PW, Geier PW, Thompson CR, Currie RS, Schlegel AJ, Holman JD, Hudson KA, Shoup DE, Moechnig MJ, Grichar WJ, Bean BW (2011) Efficacy of postemergence herbicides tank mixes in arylox- yphenoxypropionate-resistant grain sorghum. Crop Prot 30:1623-1628

Andersen RN, Ford JH, Lueschen WE (1982) Controlling volunteer corn (Zea mays) in soybeans (Glycine max) with diclofop and glyphosate. Weed Sci 30:132-136

Andersen RN, Geadelmann JL (1982) The effect of parentage on the control of volunteer corn (Zea mays) in soybeans (Glycine max). Weed Sci 30:127-131

Anonymous (2014) Liberty 280 SL herbicide specimen label. http://www.cdms.net/LDat/ldUA5004.pdf. Accessed: August 15,2014

Askew SD, Shaw DR, Arnold JC (1997) Weed control in Liberty-Link soybean. Page 59 in Proceedings of 50th Annual Meeting of Southern Weed Science Society, Houston, TX

Aulakh JS, Jhala AJ (2015) Comparison of glufosinate-based herbicide programs for broad-spectrum weed control in glufosinate-resistant soybean. Weed Technol 29:419-430

Aulakh JS, Price AJ, Balkcom KS (2011) Weed management and cotton yield under two row spacings in conventional and conservation tillage systems utilizing conventional, glufosinate-, and glyphosate-based weed management systems. Weed Technol 25:542-547

Aulakh JS, Price AJ, Enloe SF, Santen EV, Wehtje G, Patterson MG (2012) Integrated Palmer amaranth management in glufosinate-resistant cotton: I. Soil-inversion, high-residue cover crops and herbicide regimes. Agronomy 2:295-311

Aulakh JS, Price AJ, Enloe SF, Wehtje G, Patterson MG (2013) Integrated Palmer amaranth management in glufosinateresistant cotton: II. Primary, secondary and conservation tillage. Agronomy 3:28-42

Avila-Garcia WV, Sanchez-Olguin E, Hulting AG, MallorySmith C (2012) Target-site mutation associated with glufosinate resistance in Italian ryegrass (Lolium perenne L. ssp. multiflorum). Pest Manag Sci 68:1248-1254

Barnett KA, Culpepper AS, York AC, Steckel LE (2013) Palmer amaranth (Amaranthus palmeri) control by glufosinate plus fluometuron applied postemergence to WideStrike ${ }^{\circledR}$ cotton. Weed Technol 27:291-297

Beckett TH, Stoller EW (1988) Volunteer corn (Zea mays) interference in soybeans (Glycine max). Weed Sci 36:159-166

Beckett TH, Stoller EW, Bode LE (1992) Quizalofop and sethoxydim activity as affected by adjuvants and ammonium fertilizers. Weed Sci 40:12-19

Beckie HJ, Hall LM (2014) Genetically-modified herbicideresistant (GMHR) crops a two-edged sword? An Americas perspective on development and effect on weed management. Crop Prot 66:40-45

Beckie HJ, Tardif FJ (2012) Herbicide cross resistance in weeds. Crop Prot 35:15-28

Bethke RK, Molin WT, Sprague C, Penner D (2013) Evaluation of the interaction between glyphosate and glufosinate. Weed Sci 61:41-47

Beyers JT, Smeda RJ, Johnson WG (2002) Weed management programs in glufosinate-resistant soybean (Glycine max). Weed Technol 16:267-273

Burke IC, Askew SD, Corbett JL, Wilcut JW (2005) Glufosinate antagonizes clethodim control of goosegrass (Eleusine indica). Weed Technol 19:664-668 
Castle LA, Wu GS, McElroy D (2006) Agricultural input traits: past, present and future. Curr Opin Biotechnol 17:105-112

Chahal PS, Bernards ML, Kruger GR, Blanco-Canqui H, Jhala AJ (2015) Impact of glyphosate-resistant volunteer corn density, control timing, and late season emergence on soybean yield. Proceedings of 55th Annual Meeting of Weed Science Society of America (WSSA), Lexington, KY

Chahal PS, Kruger G, Blanco-Canqui H, Jhala AJ (2014) Efficacy of pre-emergence and post-emergence soybean herbicides for control of glufosinate-, glyphosate-, and imidazolinone-resistant volunteer corn. J Agric Sci 6:131-140

Clewis SB, Thomas WE, Everman WJ, Wilcut JW (2008) Glufosinate-resistant corn interference in glufosinate-resistant cotton. Weed Technol 22:211-216

Coetzer E, Al-Khatib A, Peterson DE (2002) Glufosinate efficacy on Amaranthus species in glufosinate-resistant soybean. Weed Technol 16:326-331

Colby SR (1967) Calculating synergistic and antagonistic responses of herbicide combinations. Weeds 15:20-22

Corbett JL, Askew SD, Thomas WE, Wilcut JW (2004) Weed efficacy evaluations for bromoxynil, glufosinate, glyphosate, pyrithiobac, and sulfosate. Weed Technol 18:443-453

Craigmyle BD, Ellis JM, Bradley KW (2013) Influence of herbicide program on weed management in soybean with resistance to glufosinate and 2,4-D. Weed Technol 27:78-84

Culpepper AS, York AC, Brownie C (1999) Influence of bromoxynil on annual grass control by graminicides. Weed Sci 47:123-128

Culpepper AS, York AC, Jennings KM, Batts RB (2000) Weed management in glufosinate- and glyphosate-resistant soybean (Glycine max). Weed Technol 14:77-88

Culpepper AS, York AC, Jennings KM, Batts RB (1998) Interaction of bromoxynil and postemergence graminicides on large crabgrass (Digitaria sanguinalis). Weed Technol 12:554559

Culpepper AS, York AC, Roberts P, Whitaker JR (2009) Weed control and crop response to glufosinate applied to 'PHY 485 WRF' cotton. Weed Technol 23:356-362

Davis VM, Marquardt PT, Johnson WJ (2008) Volunteer corn in northern Indiana soybean correlates to glyphosate-resistant corn adoption. Online. Crop Manag. DOI: 10.1094/ CM-2008-0721-01-BR

Deen W, Hamill A, Shropshire C, Soltani N, Sikkema PH (2006) Control of glyphosate-resistant corn (Zea mays) in glyphosate-resistant soybean (Glycine max). Weed Technol 20:261-266

Devine MD, Duke SO, Fedtke C (1993). Inhibition of amino acid biosynthesis. Pages 251-291 in Physiology of Herbicide Action. Englewood Cliffs, NJ: Prentice-Hall

Earnest LD, Webster EP, Hooks GG (1998) Systems for weed control in Liberty tolerant corn. Page 261 in Proceedings of 51st Southern Weed Science Society meeting, Birmingham, AL

Ganie ZA, Stratman G, Jhala AJ (2015) Response of selected glyphosate-resistant broadleaved weeds to premix of fluthiacetmethyl and mesotrione (Solstice ${ }^{\mathrm{TM}}$ ) applied at two growth stages. Can J Plant Sci. DOI: 10.4141/CJPS-2014-429

Gardner AP, York AC, Jordan DL, Monks DW (2006) Glufosinate antagonizes postemergence graminicides applied to annual grasses and johnsongrass. J Cotton Sci 10:319-327
Heap IM (2014a) International survey of herbicide resistant weeds: weeds resistant to EPSP synthase inhibitors (G/9). http:// www.weedscience.org/summary/MOA.aspx?MOAID=12. Accessed August 12, 2014

Heap IM (2014b) International survey of herbicide resistant weeds: weeds resistant to the herbicide glufosinate-ammonium. http://www.weedscience.org/summary/ResistByActive. aspx. Accessed October 27, 2014

Hinchee MAW, Padgette SR, Kishore GM, Delannay X, Fraley RT (1993) Herbicide-tolerant crops. Pages 243-263 in Kung S, Wu R, eds. Transgenic Plants. Volume 1. San Diego, CA: Academic Press

Holshouser DL, Coble HD (1990) Compatibility of sethoxydim with five postemergence broadleaf herbicides. Weed Technol $4: 128-133$

Jalaludin A, Ngim J, Bali BB, Zazali A (2010) Preliminary findings of potentially resistant goosegrass (Eleusine indica) to glufosinate-ammonium in Malaysia. Weed Biol Manag 10:256-260

Jhala AJ, Knezevic SZ, Ganie ZA, Singh M (2014) Integrated weed management in corn (Zea mays L.). Pages 177-196 in Chauhan B, Mahajan G, eds. Recent Advances in Weed Management. New York: Springer

Jhala AJ, Ramirez AHM, and Singh M (2013) Tank mixing saflufenacil, glufosinate and indaziflam improved burndown and residual weed control. Weed Technol 27:422-429

Johnson DB, Norsworthy JK, Scott RC (2014) Herbicide programs for controlling glyphosate-resistant johnsongrass (Sorghum halepense) in glufosinate-resistant soybean. Weed Technol 28:10-18

Jugenheimer RW (1976) Heterosis. Pages 55-60 in Sprague GF, Dudley JW, eds. Corn: Improvement, Seed Production, and Uses. New York: John Wiley \& Sons

Kaur S, Sandell LD, Lindquist JL, Jhala AJ (2014) Glyphosateresistant giant ragweed (Ambrosia trifida) control in glufosinate-resistant soybean. Weed Technol 28:569-577

Krupke C, Marquardt PT, Johnson WG, Weller S, Conley SP (2009) Volunteer corn presents new challenges for insect resistance management. Agron J 101:797-799

Marquardt P, Krupke C, Johnson WG (2012) Competition of transgenic volunteer corn with soybean and the effect on western corn rootworm emergence. Weed Sci 60:193-198

Norsworthy JK, Ward SM, Shaw DR, Llewellyn RS, Nichols RL, Webster TM, Bradley KW, Frisvold G, Powles SB, Burgos NR, Witt WW, Barrett M (2012) Reducing the risks of herbicide resistance: Best management practices and recommendations. Weed Sci 60:31-62

Owen M (2008) Weed species shifts in glyphosate-resistant crops. Pest Manag Sci 64:377-387

Sarangi D, Sandell LD, Knezevic SZ, Aulakh JS, Lindquist JL, Irmak S, Jhala AJ (2015) Confirmation and control of glyphosate-resistant common waterhemp (Amaranthus rudis) in Nebraska. Weed Technol 29:82-92

Shauck TC, Smeda RJ (2012) Control of glyphosate-resistant corn (Zea mays) with glufosinate or imazethapyr plus imazapyr in a replant situation. Weed Technol 26:417-421

Shaw JT, Paullus JH, Luckmann WH (1978) Corn rootworm oviposition in soybeans. Econ Entomol 71:189-191 
Sikkema PH, Soltani N (2014) Control of volunteer Enlist corn in soybean. Page 69 in Proceedings of the 69th North Central Weed Science Society Annual Meeting. Minneapolis, MN: North Central Weed Science Society

Singh M, Tucker DPH (1987) Glufosinate (Ignite): a new promising postemergence herbicide for citrus. Pages 58-61 in Proceedings of the 100th Annual Meeting of the Florida State Horticulture Society, Orlando, FL

Soltani N, Shropshire C, Sikkema PH (2006) Control of volunteer glyphosate-tolerant maize (Zea mays) in glyphosatetolerant soybean (Glycine max). Crop Prot 25:178-181

Steckel GJ, Wax LM, Simmons FW, Phillips WH, II (1997) Glufosinate efficacy on annual weeds is influenced by rate and growth stage. Weed Technol 11:484-488

Steckel LE, Thompson MA, Hayes RM (2009) Herbicide options for controlling glyphosate-tolerant corn in a corn replant situation. Weed Technol 23:243-246

Terry RM, Marquardt PT, Camberato JJ, Johnson WG (2012) Effect of plant nitrogen concentration on the response of glyphosate-resistant corn hybrids and their progeny to clethodim and glufosinate. Weed Sci 60:121-125

[USDA] U.S. Department of Agriculture-Economic Research Service (2014) http://www.ers. usda.gov/data-products/ adoption-of-genetically-engineered-crops-in-the-us/ recent-trends-in-ge-adoption.aspx Accessed October 27, 2014
Vidrine PR, Reynolds DB, Blouin DC (1995) Grass control in soybean (Glycine max) with graminicides applied alone and in mixtures. Weed Technol 9:68-72

Wendler C, Barniski M, Wild A (1990) Effect of phosphinothricin (glufosinate) on photosynthesis and photorespiration of C3 and C4 plants. Photosynth Res 24:55-61

Whitaker JR, York AC, Jordan DL, Culpepper AS (2011a) Weed management with glyphosate- and glufosinate-based systems in PHY 485 WRF Cotton. Weed Technol 25:183191

Whitaker JR, York AC, Jordan DL, Culpepper AS, Sosnoskie LM (2011b) Residual herbicides for Palmer amaranth control. Cotton Sci 15:89-99

Wild A, Wendler C (1991) Effect of glufosinate (phosphinothricin) on amino acid content, photorespiration, and photosynthesis. Pesticide Sci 30:422-424

Wilson R, Sandell LD, Klein R, Bernards M (2010) Volunteer corn control. Pages 212-215 in Proceedings of 2010 Crop Production Clinics. Lincoln, NE: University of NebraskaLincoln Extension

Young BG, Hart SE (1997) Control of volunteer sethoxydimresistant corn (Zea mays) in soybean (Glycine max). Weed Technol 11:649-655

Received January 1, 2015, and approved April 17, 2015. 